\title{
Perceived value of organizational foresight processes: effects of the illusion of control and individual foresight
}

\author{
Natália Borges ${ }^{1}$ \\ natalia_marroni@hotmail.com | (1) 0000-0001-6716-1608 \\ Raquel Janissek-Muniz ${ }^{1}$ \\ rjmuniz@ufrgs.br | (10 0000-0002-0657-6559
}

\begin{abstract}
This research proposes an investigation into the reasons for low adherence for foresight processes in organizations. Studies involving the relevance of foresight processes have become increasingly frequent, driven by an environment of increasing volatility, uncertainty, ambiguity, and complexity. Despite the importance of the topic, which seeks to enable organizations to anticipate threats and opportunities from the environment through methods, there is still little adherence to these practices, which justifies the purpose of this investigation. To achieve the proposed objective, a questionnaire was structured. Then, it was applied via electronic survey, allowing the observation of the effects of the illusion of control and individual foresight activities on the perceived value of formal foresight processes in organizations. The data were analyzed based on structural equations modeling with estimation through Partial Least Square (PLS). The sample was composed of 185 executives from the financial and technological sectors, and a reduction to the perceived value of foresight processes was identified, as a result of the illusion of control and individual practices of these activities. These results contribute to the understanding of the low adherence of foresight processes, from the perspective of cognitive biases attributed to the decision-maker.
\end{abstract}

\section{KEYWORDS}

Foresight, Individual Foresight, Illusion of Control, Perceived Value

${ }^{1}$ Universidade Federal do Rio Grande do Sul, UFRGS, Porto Alegre, RS, Brasil

Received: 02/06/2020.

Revised: 06/25/2020.

Accepted: 12/21/2020.

Published Online: 07/26/2021

DOI: http://dx.doi.org/10.15728/bbr.2021.18.5.3 


\section{INTRODUCTION}

The use of terms such as "foresight", "strategic foresight" and "corporate foresight" has been growing quickly lately. The growth of this theme is associated with the reality of disruptive transformations to which organizations are inserted, generating the need to anticipate the opportunities and threats arising from this new scenario. The concept of foresight has its base in studies on environmental scanning, originally coined by Aguilar (1967) and is linked to weak signal management and organizational strategic planning (Ansoff, 1975). With the growth of these studies, other terms were associated with the original concept, opening space for different approaches, andmaking it difficult to frame the theoretical subject (Rohrbeck, Battistella \& Huizingh, 2015). Although there are terms that come close to the meaning of foresight (such as "anticipation", "environmental scanning" and, in some cases, even "forecast"), it is understood that these terms do not contemplate the completeness of the concept, which is why the term was used as coined, foresight, even in the Portuguese version of this paper.

In general, this practice was structured to generate knowledge that should assist senior executives in making decisions about the future of their organizations and remains widely used for that purpose (Aguilar 1967). This practice ensures benefits by taking advantage of opportunities or protecting themselves from threats from the external environment (Koller, 2009), which is why it is still expressively associated with strategic organizational planning (Buehring \& Liedtka, 2018) in an orientation of future studies seeking to anticipate possible scenarios.

Regarding the methods used to achieve this objective, the academic literature related to foresightremains diverse (Soares, Florêncio, Assis, Digolin, Gontijo \& Canesin, 2019), pointing to terms such as intelligence, scenario planning, strategic intelligence, and environmental scanning, among others. Additionally, different techniques are proposed, such as future scenarios, scanning, road mapping, brainstorming, stakeholder mapping, expert panels, relevance trees, etc. (Popper, 2008), which makes this field still have the need to be better explored (Rohrbeck et al., 2015) to establish confluences in terms of understanding concepts and nomenclatures.

The activities performed for foresight operationalization are relevant in both an organizational and an individual approach. The difference between these approaches is the difficulty of organizations to maintain teams dedicated to foresight in a systematic way (Barnard-Wheels, 2017). Executives then choose to perform the activities individually and spontaneously, without an associated organizational process (Borges \& Janissek-Muniz, 2017; Tapinos \& Pyper, 2018). The effects of individual practices, besides the discontinuity and lack of organizational controls, are the absence of a collective interpretation of information, leading to individual decision-making in a context of complexity and uncertainty, with implications at the strategic level.

When making strategic decisions under uncertainty, executives are subjected to cognitive biases that limit the quality of the decision obtained in the strategic process (Bazerman \& Moore, 1994; Kahneman \& Lovallo, 1993). The Theory of Illusion of Control (IOC) describes the tendency of decision-makers to overestimate their influence on casual events (Langer, 1975) by weakening analytical reasoning, which is a relevant part of the decision-making process (Stefan \& David, 2013). This leads professionals to think about certainties, preventing reflection in complex situations, directly affecting the organizational strategic planning (Meissner \& Wulf, 2016). 
BBR

18

518

Considering that foresight processes, although relevant, are still poorly systematized and their value is still little explored by executives (Harrysson, Métayer \& Sarrazin, 2014), the possible relationships between individual foresight practices and their effects on the value perception of an organizational approach are questioned. There is also the questioning about possible influences of cognitive biases — specifically the illusion of control — on this perception arising.

Given the above, this research has the objective of investigating the individual approach and the bias of IOC, and its effects on the perception of value to foresight organizational processes and the intention for its adoption. To accomplish this objective, a survey was conducted with 185 executives from the financial and technological sectors, identifying the variations in the perceived value of foresight processes as a result of the illusion of control and individual practices of these activities.

\subsection{Individual and Organizational FORESIGHT}

The foresight has been studied under different approaches for over 60 years. Different denominations are used to enable the company to anticipate events that represent structural changes in its market, taking advantage of opportunities or preventing threats arising from these changes (Soares et al., 2019).

The foresight process is not just about collecting information from the outside environment or from ones' knowledge. It is a process composed of the steps referred to in this work as "Informational Search", "Sensemaking" and "Information Use", which can generate results linked to innovation (Ruff, 2006; Rohrbeck, 2012), organizational performance (Garg, Walters \& Priem, 2003), and competitive advantage (Rohrbeck et al., 2015).

Authors such as Lesca (2003), Kaivo-Oja (2017) and Schoemaker (2019) raise the need for a systematized approach, with structuring of formal processes and roles that will be performed by different professionals. The importance of multidisciplinarity in achieving results is discussed, as well as the relevance of the collective factor in creating the meaning of information (Lesca, 2003; Sarpong \& Maclean, 2014). In addition, an organizational approach enables the observation of indirect effects such as strategic alignment (Kumar et al., 2001; Battistella, 2014) and increased organizational learning (Rohrbeck \& Schwartz, 2013; Battistella, 2014; Peter \& Jarratt, 2015).

On the other hand, an individualoriented approach is observed, linking the stages of foresight to the roles of the senior executives (Lau et al., 2012; Barron, Hultén \& Vanyushyn, 2015). In this approach, the strategic level concentrates the entire foresight activity plan. This difference in approaches configures how activities will be performed, their continuity and the level of dependence of the organization on specific individuals (Borges \& Janissek-Muniz, 2017). Figure 1 presents the distribution of the macro activities of the foresight process considering the two approaches.

According to Reger's (2001) study, it is observed that foresight processes are poorly structured, often occurring unconsciously, without defined phases, which incurs difficulties in describing the activity, reinforcing the individual approach. These characteristics associated with the individual foresight process limit the quality of the decision obtained in the strategic process (Bazerman $\&$ Moore, 1994; Kahneman \& Lovallo, 1993), since executives are susceptible to cognitive bias. Next, the illusion of control bias will be discussed, in an attempt to understand its effects on the approaches presented so far. 


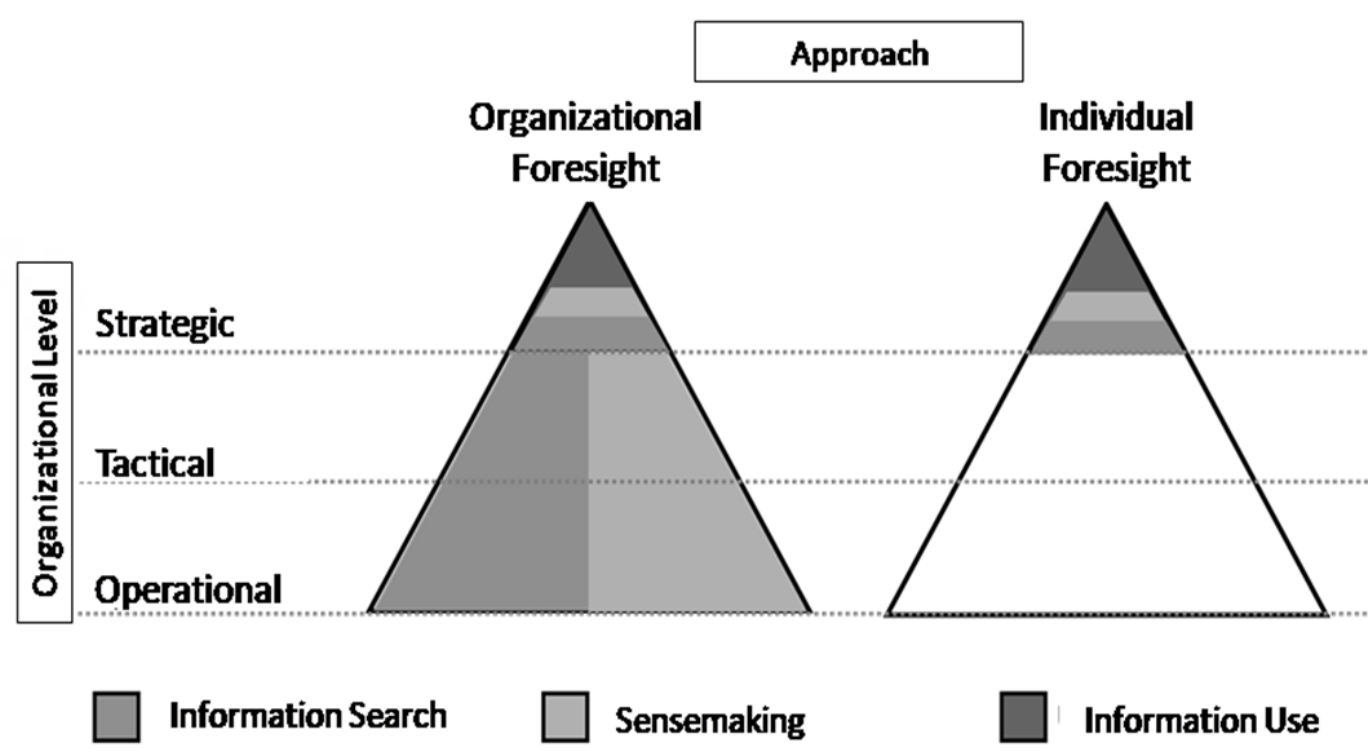

Figure 1. Different Foresight Approaches

Source: Elaborated by the Authors

\subsection{Illusion of Control and the Organizational Context}

White (1959) describes control as an intrinsic and extrinsic human need related to interaction and changes in the external environment. De Charms (2013) refers to the desire for effectiveness in controlling and modifying the external environment as the main motivational propensity of the human being. According to Skinner (1995), people need control experiences, and the need for competence or effectiveness is considered universal.

The concept of Illusion of Control was introduced by Langer (1975), who argued that the phenomenon refers to an expectation of success considering a probability improperly higher than what the objective probability would justify. According to Taylor and Brown (1988), IOC ends up acting as a mechanism that reduces the understanding of risks, leading the individuals to conduct their activities without being barred by fear. Sivanathan et al. (2008) show that power influences individuals to the point of losing their ability to interact with and adapt to the real world.

In scenarios of uncertainty, individuals try to simplify their decisions and use intuition, deciding based on associations to lived experiences (Dijksterhuis, Bos, Nordgren \& Van Baaren, 2006; Dane \& Pratt, 2007), which can cause errors of judgment (Kahneman \& Tversky, 1979; Tversky \& Kahneman, 1974). In terms of organizational strategy, IOC reduces perceived risk (Simon et al., 2000) and executive predictability (Durand, 2003), reducing then the overall quality of decisions obtained (Duhaime \& Schwenk, 1985) and of the performance (Blenko et al., 2010; Milkman et al. 2009), with decisions based on overconfidence (Montier, 2009).

As a consequence of what has been seen so far, and of the needs for the present investigation, it is necessary to understand the traits in the individual that configure the illusion of control in an organizational context. The following will seek this deepening.

\subsection{CHARACTERISTICS OF THE ILLUSION OF CONTROL IN INDIVIDUALS}

The illusion of control demonstrates an individual's behavior, when one believesthat he/she had greater control over a given situation than he/she actually does (Langer, 1975). In this case, an individual believes he or she has mastery over future occurrences and a belief in the likelihood 
of what is greater than is veridically observable (Graham, Harvey \& Huang, 2009). Derivations from IOC in individuals are overconfidence (Montier, 2009) and little value attributed to risks (Laroche \& Nioche 2015; Langer, 1975; Schwenk, 1984, 1988).

Schwenk (1988) points out that the illusion of control bias represents the excess of confidence in one's own ability to produce positive results; the individual constantly seeks to identify ways to control the results to be obtained and, to this end, formulates hypotheses about the effects of his actions on these results (Schwenk, 1988).

March and Shapira (1987) found that company managers show signs of illusion of control by minimizing probabilities of failure. Ferreira and Yu (2003) observed behaviors that were discrepant with the theoretical models of rational expectations and consistent with the literature on behavioral finance. These professionals demonstrated to be excessively confident in their abilities to predict the market, which constitutes evidence that they can make systematic errors when analyzing the information. Such result is added to the other groups of professionals in which there was already found overconfidence, such as engineers (Kidd, 1970), doctors (Oskamp, 1965), managers (Edward \& Schoemaker, 1992) and entrepreneurs (Buzenitz \& Barney, 1997).

In terms of low value attributed to risks, the greater the perception of control, the greater the probability of underestimating risks. The misconceptions regarding the illusion of control will lead the individual to overestimate the success of a task, reducing the value to the risks assigned (Schwenk, 1988). Even when the information presented is unequivocal, there is a tendency to wait for confirmation from alternative sources before deciding on risk protection action (Choo $\&$ Nadarajah, 2014). The subject touches on the "normalcy bias" - a tendency to underestimate the probability of a disaster and its dangerous effects (Omer \& Alon, 1994), or the tendency in any kind of crisis for people to initially interpret their situation as safe (Kuligowski \& Gwynne, 2010). Individuals tend to believe in the less alarming options whenever they are presented with conflicting or ambiguous information about the danger (Omer \& Alon, 1994).

Based on what has been shown, it is possible to associate some characteristics to the behavior of the individual regarding overconfidence and low value to risks, as shown in Table 1.

The characteristics of overconfidence and the low value attributed to risks demonstrate that the behavior of the decision-maker can be biased due to IOC (Das \& Teng, 1999; Simon et al., 2000; Meissner \& Wulf, 2016). Among the possible implications related to this theme, there is evidence about the foresight process (Barnes, 1984; Durand, 2004; Merkle, 2017), from which arises questioning about the executive's own perception of value to a formal foresight process, when it is influenced by the IOC.

\subsection{Perceived Value and Intention to Adopt to Foresight Processes}

The concept of perceived value is based on the idea of adding perceptions of different product benefits and also of the associated compensations. Perceived value research is more related to business-to-consumer exchange contexts, while there is a shortage of B2B research (Brei \& Rossi, 2005; Gosling \& Lago, 2006; Lacerda \& Mendonça, 2010). However, it is relevant to deepen this theme as well in the B2B environment, expanding the knowledge of the attributes considered important and their relationship with perceived value (Boksberger \& Melsen, 2011). 
Table 1

Characteristics of the Illusion of Control in Individuals

\begin{tabular}{|c|c|}
\hline Characteristics & Authors \\
\hline $\begin{array}{l}\text { Assigns to oneself qualities or characteristics } \\
\text { above the real ones }\end{array}$ & $\begin{array}{l}\text { Christensen-Szalanski; Bushyhead (1981) } \\
\text { Buehler, Griffin; Ross (1994) } \\
\text { Clayson (2005) } \\
\text { Presson; Benassi (1996) } \\
\text { Buehler, Griffin; Ross (1994) } \\
\text { Keh, Der Foo; Lim (2002) } \\
\text { Graham, Harvey e Huang (2009) }\end{array}$ \\
\hline Believes to have above average skills & $\begin{array}{l}\text { Bazerman; Moore (1994) } \\
\text { Svenson (1981) } \\
\text { Odean (1998) } \\
\text { Kahneman; Riepe (1998) } \\
\text { Baratella (2007) } \\
\text { Peterson (2008) }\end{array}$ \\
\hline Has certainty even in uncertain information & $\begin{array}{l}\text { Alpert; Raiffa (1982) } \\
\text { Klayman, Soll, Gonzalez-Vallejo; Barlas (1999) } \\
\text { Soll; Klayman (2004) } \\
\text { Taylor; Brown (1988) } \\
\text { Graham, Harvey; Huang (2009) }\end{array}$ \\
\hline Underestimates the probability of a disaster & $\begin{array}{l}\text { Omer; Alon (1994) } \\
\text { Kuligowski; Gwynne (2008) }\end{array}$ \\
\hline Difficulty in accepting a risky situation & Schwenk (1988) \\
\hline $\begin{array}{l}\text { Even with evidence of risk, awaits confirmation } \\
\text { of alternative sources }\end{array}$ & Choo; Nadarajah (2014) \\
\hline Believes that risk situations are controlled & $\begin{array}{l}\text { Taylor; Brown (1988) } \\
\text { Hammond; Horswill (2001) }\end{array}$ \\
\hline Believe in the less alarming reality & Omer; Alon (1994) \\
\hline
\end{tabular}

Source: Elaborated by the Authors

Thus, some authors have worked on the concept of perceived value under the organizational parameter, seeking the understanding of value by the organization itself in relation to the processes adopted: Niazi and Babar (2009), analyzing CMMI practices in software industries; Abdelrahman (2008), regarding organizational processes of knowledge management; Riviére (2015), proposing a perceived value model for innovation; and Chekurov et al (2018), analyzing the perceived value of the implementation of assisted manufacturing in supply chains. Borges (2020) proposes an adaptation of the Perval and ServPerval models to establish dimensions that clarify the structure of perceived value in terms of foresight processes. The themes related to the acceptance and adoption of technologies have been extensively researched over the years, beginning in 1975 with the Theory of Reasoned Action, which argued that the behavior of individuals is conditioned by the intentions of behavior, linked to positive and negative feelings of themselves (Fishbein $\&$ Azjen, 1975). Several other models related to these themes were elaborated, such as the Theory of Planned Behavior (Ajzen, 1991), Motivational Model (Davis, Bagozzi \& Warshaw, 1992) and the Technology Acceptance Model - TAM (Davis, 1989). In 2003, Venkatesh, Morris, Davis and Davis unified several of these theories into a single model that has been used to understand the 
acceptance and use of technologies: UTAUT. The basic idea regarding user acceptance models depends on the user's individual reactions to the use of information technology, on his or her intentions for the use it, that derive from the effective use of these technologies.

The behavioral intention construct which is present in the UTAUT model consists of the user's intention regarding the effective use of the system, and is an important antecedent of the individual's effective use behavior (Venkatesh et al., 2003). Although the research conducted by Venkatesh et al. was conducted in the context of technology adoption, it was considered appropriate to use the construct, since the factors that influence the intention to adopt a process may be similar to those found in the studies summarized by Venkatesh et al. (2003).

\subsection{Research Assumptions}

Foresight processes generate positive results for organizations (Jennings \& Lumpkin, 1992; Ruff, 2006; Rohrbeck, 2012; Battistella, 2014), highlighting their importance from the point of view of organizational strategy management. However, the bias of IOC generates effects on decision-makers in situations of uncertainty, affecting the ability to glimpse risks or collaborating with overconfidence behaviors. These characteristics of the illusion of control can affect decisionmakers' perception of value with respect to foresight processes.

- H1: The illusion of control reduces perceived value to formal foresight organizational processes.

Foresight organizational processes have different ramifications, making it difficult to specify a "reliable" methodology (Soares et al., 2019), as well as barriers related to difficulty of implementation, credibility (Slaughter, 1990; Schwartz, 2005), and response time of the process to the company's needs (Coates, 1985; Slaughter, 1990). Some of these barriers are eliminated as individual foresight practices take shape, through the spontaneous execution of activities, which is usually attributed to company executives (Borges \& Janissek-Muniz, 2017). The hypothesis elaborated is that, when performing foresight activities in an individual way, there is a reduction in the perception of the value of organizational practices.

- H2: The performance of individual foresight practices by executives reduces perceived value to formal foresight organizational processes.

The intention of adoption for a process is usually linked to diverse background factors. Like the TAM model (Davis, 1989) which has the perceived utility as an antecedent to the attitude of use, and the UTAUT model (Venkatesh, 2003), which includes the expectation of performance as an antecedent to the intention of use, it is questionable whether the value perceived by executives to the organizational processes of foresight will influence the intention of adoption of the same.

- H3: Perceived value influences the intention of adoption to formal foresight organizational processes.

Based on these hypotheses, the method will be developed, followed by the presentation of results, discussion and final considerations of the study. 


\section{METHOD}

The survey was made operational through the application of an electronic survey, directed to executives from the Brazilian financial and technological sectors, totaling 185 valid questionnaires.

To achieve the goal, a quantitative approach was chosen, seeking to verify hypotheses and their relationships (Malhotra, 2012). Based on these, the research model (Figure 2) points to two independent variables (individual foresight and illusion of control) and two dependent variables (perceived value of foresight and intention of adoption to foresight processes).

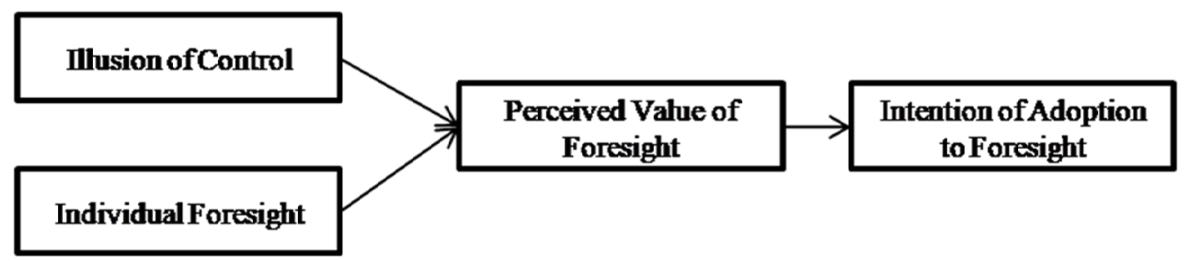

Figure 2. Research Model

Source: Elaborated by the Authors

The research instrument was developed based on the theoretical review, using a 5-point Likert concordance scalecontaining statements related to the constructs presented (Table 2).

Table 2

Constructs Developed in the Study

\begin{tabular}{ll}
\hline Constructs & Authors \\
\hline & Svenson (1981) \\
& Taylor; Brown (1988) \\
& Omer; Alon (1994) \\
Illusion of Control & Hammond; Horswill (2002) \\
& Graham; Harvey; Huang (2009) \\
& Moore; Tanlu; Bazerman (2010) \\
\hline & Lau et al (2012) \\
Individual Foresight & Barron; Hultén; Vanyushyn (2015) \\
& Tapinos; Pyper (2018) \\
& Borges; Janissek-Muniz (2018) \\
\hline & Sweenney; Soutar (2001) \\
Perceived Value to Foresight Processes & Petrick (2002) \\
& Borges (2020) \\
\hline Foresight Adoption Intention & Venkatesh (2003) \\
\hline
\end{tabular}

The questionnaires were distributed in groups specialized in the sectors under study, and targeted to executives, between the months of May and August 2019. The sample is an important component for performing statistical analysis (Hair et al., 2009), and was chosen considering the adherence of these branches to the concepts of volatility, complexity, uncertainty, and ambiguitythat contextualize the need for a structured foresight process in organizations. It was chosen to work with executives because they are responsible for strategic decision-making, and also because individual foresight processes are usually attributed to professionals who work at this organizational level. 
BBR

18

524

The G*Power 3.1.9.2 software (Faul; Erdfelder; Buchner \& Lang, 2009) was used to define the sample size. According to Ringle, da Silva and Bido (2014), one should evaluate the latent construct or variable that has the largest number of predictors as reference for determining the sample size, considering 0.80 the power of test and 0.15 the effect size, as suggested by Hair et al (2014). Including this information, the sample size required is 107 respondents. Despite indications that the SmartPLS tool does not require a minimum number of respondents (Hair et al., 2016), allowing complex analyses even with small samples, there is no consensus, which led to a search for a higher sample than indicated in $\mathrm{G}^{*}$ power.

The data collection was performed in two stages, being sent a pre-test in May/2019, when 70 answers were obtained, which served to validate the instrument (Malhotra, 2012). There was no need for adjustments, because the factor loads obtained for each variable were satisfactory. The second data collection was then carried out between June and August/2019, obtaining 197 complete questionnaires. Of these, 12 were discarded because they had more than $80 \%$ of their responses in the same alternative (Hair et al., 2014).

The analysis was carried out through the application of different techniques. Initially, Harman's factor test was performed to avoid method bias, followed by reliability analysis (Cronbach's Alpha), exploratory factor analysis, confirmatory factor analysis, and modeling of structural equations. When performing the reliability analysis, we chose to exclude the FI4 Variable, because it had Cronbach's Alpha less than 0.6, which compromised the model.

For the proposed model analysis, the convergent validity was verified through the average variance extracted (AVE), that help to understand if the model converges to a satisfactory result, if they are higher than 0.5 (Fornell \& Larcker, 1981). Then the internal consistency values were observed using Cronbach's Alpha and Composite Reliability (Hair et al., 2014), both of which are used to assess whether the sample is bias-free, or whether the responses as a whole are reliable. The third step performed was that ofdiscriminant validity of the model, with an indicator showing that the latent constructs or variables are independent of each other (Hair et al., 2014). There are two ways: observing the cross loads, where the indicators must have higher factor loads in their respective constructions than in others (Chin, 1998), and by applying the criterion of Fornell and Larcker (1981), which compares the square roots of the values of the average variance extracted from each construction with the correlations between the constructions.

For the Structural Model, Li, Su and Higgins (2015) and Hair, Ringle and Sarstedt (2011) indicate the need for Collinearity calculations that indicate whether an item can become redundant compared to others (Variance Inflation Factor - VIF); the Coefficient of Determination $\left(\mathrm{R}^{2}\right)$, which indicates the quality of the adjusted model, the Predictive Validity $\left(Q^{2}\right)$, which expresses how close the model is to what was expected of it; the Effect Size $\left(\mathrm{f}^{2}\right)$, indicating the usefulness of each Constructo in the model; and the t-test (t-student) which evaluates the significance of correlations and regressions. Table 3 presents the summarized information verified in the model analysis. 
Table 3

Model validation steps

\begin{tabular}{|c|c|c|c|}
\hline Topic & Indicator & Reference Value & Source \\
\hline Convergent Validity & $\begin{array}{l}\text { Average Variance } \\
\text { Extracted (AVE) }\end{array}$ & $>0.5$ & Fornell \& Larcker (1981) \\
\hline \multirow{2}{*}{ Internal Consistency } & Cronbach's Alpha & $>0.6$ & Hair et al. (2014) \\
\hline & Composite Reliability & $>0.7$ & Hair et al. (2014) \\
\hline \multirow{2}{*}{ Discriminant Validity } & Cross Loadings & \multirow{2}{*}{$\begin{array}{l}\text { higher factor loads in its } \\
\text { constructions than in others }\end{array}$} & Chin (1998) \\
\hline & $\mathrm{AVE}^{2}$ & & Fornell e Larcker (1981) \\
\hline Collinearity & VIF & $<5$ & \\
\hline $\begin{array}{l}\text { Coefficient of } \\
\text { Determination }\end{array}$ & $\mathrm{R}^{2}$ & $\begin{array}{l}2 \% \text { small } \\
13 \% \text { medium } \\
26 \% \text { large }\end{array}$ & Cohen (1988) \\
\hline Predictive Validity & $\mathrm{Q}^{2}$ & $\mathrm{Q}^{2}>0$ & Hair et al. (2014) \\
\hline Effect Size & $\mathrm{F}^{2}$ & $\begin{array}{l}0.02 \text { small } \\
0.15 \text { medium } \\
0.35 \text { large }\end{array}$ & Hair et al. (2014) \\
\hline T-test & $\mathrm{t}$-student & $\mathrm{T} \geq 1.96$ & Hair et al. (2014) \\
\hline
\end{tabular}

Source: Elaborated by the Authors

The operationalization of these validation steps occurred with the use of SPSS and SmartPLS software. Based on what has been exposed so far, the research was applied, and its analyses and results are presented in the following section, followed by discussions regarding the result and final considerations.

\section{RESULTS}

In order to achieve the objective of this study, 185 valid questionnaires were received, as explained in the method section. Of these, the majority of respondents are male (68\%). The predominant sector in terms of responses received is the financial sector $(62 \%)$, and the positions held by the executive respondents are those of manager $(35 \%)$, superintendent $(7 \%)$, director $(20 \%)$, partner (31\%), and counselor (7\%). The predominant age group is from 31 to 40 years old, with $34 \%$ of the respondents, of which $40 \%$ had occupied their positions for less than 5 years.

In a brief descriptive analysis of the data obtained, taking into consideration the average of the results, it is observed that the illusion of control is, in a very subtle way, more observed in male respondents. More expressively, it is observed that the age group above 60 years is the one that has the highest agreement with the characteristics of the IOC. In terms of positions held, the functions of superintendent and counselor are the most prone to IOC behavior, with managers being the ones with the lowest indicator of this behavior. In terms of time of experience, the differences are subtle, being those with more than 10 years of experience the most prone to the illusion of control. And, finally, in the field of operation, also with a subtle difference, executives from the financial sector present a higher level of IOC than the executives from the technological sector. These data are shown in Table 4. 
BBR

18

526

Table 4

Illusion of Control in the Different Characteristics of the Sample

\begin{tabular}{|c|c|c|c|c|c|c|c|c|c|c|c|c|c|c|c|c|}
\hline \multicolumn{2}{|c|}{ Gender } & \multicolumn{5}{|c|}{ Age Range } & \multicolumn{5}{|c|}{ Position } & \multicolumn{2}{|c|}{ Sector } & \multicolumn{3}{|c|}{ Experience } \\
\hline 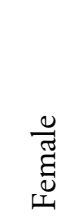 & $\frac{0}{\sum^{\pi}}$ & $\begin{array}{l}8 \\
\wedge\end{array}$ & $\frac{i}{i}$ & $\frac{\text { P+ }}{\stackrel{1}{m}}$ & 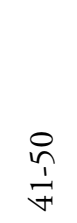 & $\begin{array}{l}\stackrel{0}{1} \\
\stackrel{i}{n}\end{array}$ & 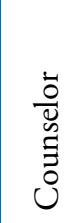 & 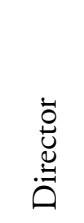 & 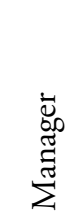 & 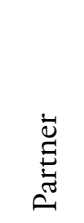 & 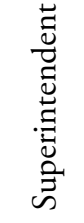 & 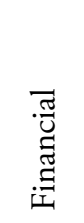 & 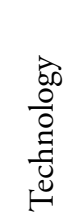 & $\tilde{v}$ & $\stackrel{\circ}{\stackrel{\circ}{\wedge}}$ & $\begin{array}{l}\stackrel{0}{1} \\
\stackrel{0}{3} \\
\text { in }\end{array}$ \\
\hline 3.07 & 3.22 & 3.62 & 3.14 & 2.88 & 3.49 & 3.07 & 3.68 & 3.19 & 2.88 & 3.22 & 3.74 & 3.30 & 2.97 & 3.13 & 3.32 & 3.11 \\
\hline
\end{tabular}

Source: Research Data

For the analysis of the obtained data, in line with the methodological procedures chosen to achieve the objectives of this research, the result of Harman's test was initially observed. The test presented 4 analysis factors, the largest of which results in $40 \%$ of the variance, being an indication that, in this aspect, the model is as expected. The reliability analysis was also performed based on the results of Cronbach's Alpha, which should be higher than 0.7 (Hair et al., 2016).

Then, the analysis was performed to validate the proposed measurement model, starting with the exploratory factor analysis, useful to verify the existence of correlations between variables and to identify interrelated variables (Koufteros, 1999; Hair et al. 2009), starting with the KMO and Barlett's sphericity tests. These analyses are presented in Table 5.

Table 5

$K M O$, Cronbach's Alpha and Barlett Sphericity

\begin{tabular}{lccc}
\hline Factor & Cronbach's Alpha & KMO & BS \\
\hline Illusion of Control & 0.886 & 0.864 & .000 \\
Individual Foresight & 0.847 & 0.815 & .000 \\
Perceived Value & 0.846 & 0.801 & .000 \\
Intention of Adoption & 0.815 & 0.685 & .000 \\
\hline
\end{tabular}

Source: Elaborated by the Authors

Then, the factorial analysis observed the factorial loads indicated for each variable, which must be greater than 0.4 in its constructions and greater than the loads obtained for the variable in the other constructions (Table 6).

For analysis of the measurement model, the convergent validity was verified, having as indicator the mean variance extracted. The results were satisfactory because all latent variables presented results higher than 0.5 . The discriminant validity was based on the square root value of the AVE, noting that its value must be higher than the other LVs of the model, which is also confirmed. The reliability of the model was evaluated taking into consideration the Cronbach's Alpha and Composite Reliability indicators, both within the recommended standards (Table 7). 
Table 6

Exploratory Factorial Analysis

\begin{tabular}{lcccc}
\hline \multicolumn{5}{c}{ Components } \\
\hline IOC1 & Illusion of Control & Individual Foresight & Perceived Value & Intention of Adoption \\
IOC2 & .846 & .100 & -.251 & .089 \\
IOC3 & .840 & .182 & -.044 & -.124 \\
IOC4 & .805 & .233 & -.066 & -.120 \\
IOC5 & .719 & .309 & -.106 & -.260 \\
IF1 & .722 & .125 & -.085 & -.338 \\
IF2 & .099 & .820 & -.105 & -.115 \\
IF3 & .177 & .810 & -.091 & -.132 \\
IF5 & .210 & .660 & -.384 & -.098 \\
PVF1 & .142 & .769 & -.198 & -.179 \\
PVF2 & -.200 & -.270 & .730 & .297 \\
PVF3 & -.181 & -.172 & .749 & .302 \\
PVF4 & -.200 & -.265 & .799 & .007 \\
AD1 & .068 & -.062 & .752 & .299 \\
AD2 & -.252 & -.241 & .208 & .726 \\
AD3 & -.058 & .017 & .258 & .817
\end{tabular}

Source: Elaborated by the Authors

Table 7

Measurement Model

\begin{tabular}{lcccc}
\hline Latent Variables & 1 & 2 & 3 & 4 \\
\hline 1 - Illusion of Control & $\mathbf{0 . 8 3 3}$ & & & \\
2 - Individual Foresight & 0.465 & $\mathbf{0 . 8 2 7}$ & & \\
3 - Intention of Adoption & -0.395 & -0.523 & $\mathbf{0 . 8 2 8}$ & $\mathbf{0 . 8 6 1}$ \\
4 - Perceived Value & -0.426 & -0.400 & 0.567 & 0.896 \\
\hline Compound reliability & 0.919 & 0.896 & 0.897 & 0.741 \\
\hline
\end{tabular}

Note: Values on the diagonal are the square root of the AVE

Regarding the evaluation of the structural model, the collinearity was verified through the VIF values, all below 5, which is the established criterion for this analysis. The effect size was verified based on the Cohen Indicator $\left(\mathrm{F}^{2}\right)$, which indicates the average effect of the variables Individual Foresight and Illusion of Control on the perceived value, and high effect between the variable Perceived Value and the Intention of Adoption. The coefficient of determination presents moderate effect in both situations, being an acceptable value for the proposed model (Table 8). 
Table 8

Structural Model

\begin{tabular}{lccccccc}
\hline Hypotheses & VIF & $\mathrm{F}^{2}$ & $\begin{array}{c}\text { Structural } \\
\text { Coefficient }\end{array}$ & $\begin{array}{c}\text { Standard } \\
\text { Error }\end{array}$ & T Value & P Value & Adjusted R \\
\hline $\mathrm{H} 1$ & 1.276 & 0.042 & -0.193 & 0.066 & 2.950 & 0.003 & 0.296 \\
$\mathrm{H} 2$ & 1.276 & 0.211 & -0.434 & 0.062 & 7.026 & 0.000 & \\
$\mathrm{H} 3$ & 1.000 & 0.475 & 0.567 & 0.047 & 11.977 & 0.000 & 0.318 \\
\hline
\end{tabular}

Source: Elaborated by the Authors

Once the questions related to the analysis of the model are observed, it is verified, through the T-value results, that the hypotheses of the study are confirmed. Both the illusion of control bias and individual foresight practices negatively influence the perceived value of these practices from an organizational perspective. And the perceived value of the executives influences the intention of adoption to the processes. The analyses and discussions of the results obtained, as well as the final considerations of this research, will be presented below.

\section{FINAL DISCUSSIONS AND CONSIDERATIONS}

The foresight processes, although admittedly important, still have little adherence to management practices. This is one of the motivators for the execution of this research, which sought to understand the effects of the illusion of control and individual practices to the perceived value of foresight as a structured process.

To carry out the research, the characteristics common to individuals who present illusion of control were observed. Furthermore, the activities and stages of a foresight process were verified, allowing the structuring of a measurement model capable of relating the constructs, in order to verify the possible effects of these phenomena on the perceived value of the foresight process and, later, on the intention of adoption of these processes. Statistical criteria in the literature were used to validate the model.

The sample was composed by executives from the financial and technological sectors, given the reality of transformation that these sectors are going through, and the adherence of this reality to foresight processes. Since the objective established for this study is to establish the relationships between the illusion of control, the individual foresight, the perceived value of the foresight and the intention of adoption of the foresight, using the modeling of structural equations for data analysis; descriptive analyses of the data and comparisons regarding the characteristics of the respondents were not explored in depth in the results section. Due to the sample size required for the modeling of structural equations made explicit in the method, it was not possible to make comparisons between the different sectors using the model.

Exactly because this is a study that explores the behavior of the individual, characteristics such as gender, age, and time of experience can influence the illusion of control. Sivanathan et al (2008) observe that the illusion of control, in corporate environments, increases as the individual's power increases, which could be observed in part in the results, concluding that executives in the position of "counselors" showed superior IOC behaviors than others. In counterpoint to this statement, executives with superintendent positions presented superior IOC behaviors to directors and partners. A possible explanation for this situation is the fact that superintendent positions, in the context of the study, are linked to banking institutions, solid and already well structured 
in hierarchical terms. On the other hand, directors and, especially, partners, may be positions also held in fintechs that are generally less structured and have a reduced number of employees.

Regarding the results obtained, the hypothesis that the illusion of control negatively influences the perceived value of foresight processes has been validated. The confirmation of this hypothesis helps to understand that individual biases affect the intention of adoption of foresight processes, since they reduce the value perception of executives to these processes, even when in volatile, uncertain, ambiguous and complex environments, as is the case of the financial and technological sectors in the current market conjuncture.

In this sense, it is observed that there is a propensity of executives to carry out activities attributed to the foresight in an individual manner. This individualization has the potential to cause biased evaluations, since the intrinsic limitations of individuals can lead them to make misinterpretations. Thus, they believe that the external organizational environment is "under control" (Borges \& Janissek-Muniz, 2018). Moreover, in accordance with the literature on the topic, it is observed that there is, on the part of these executives, a low value attributed to risks, and also an overconfidence, where even if there is recognition of possible positive results to the organizational foresight, there is no interest in implementing this type of process in organizations. Executives show more confidence in their own methods and standards than in those proposed in a systematic and targeted manner, which signals a low value assignment to organizational foresight.

Other factors that were not observed in this investigation — such as barriers to implementing processes in organizations, costs and difficulties of foresight processes — possibly have a bearing on the results, especially considering the individual foresight practices being performed specifically by executives. In this sense, the individual practices of the foresight process are common (Du Toit, 2016, Borges, 2020), as they can be understood as spontaneous by many executives who seek to contribute to the strategy of their organizations. Thus, the confirmation of the hypothesis that individual foresight practices reduce perceived value to organizational practices also brings with it deeper questions regarding decision-makers' perception of the real need to implement these practices as a process.

\section{CONCLUSIONS}

In terms of research contribution, this is a first step towards understanding the low adoption of foresight processes in organizations. There is still much to come, but the clarity that two very present dimensions in the reality of executives effectively influence their decisions regarding foresight serves as a basis for future investigations. In addition, the structuring of what can be considered an "individual foresight practice" helps in different investigations, especially in a field where there are difficulties in developing quantitative studies.

Although the study does not seek a direct relationship between the illusion of control and individual foresight practices, this is also a possibility for future studies, considering that both can be observed in the same individual. Another issue to be observed is that the "perceived value" construct can be deepened, since there is room for a greater opening of its antecedents in the B2B context, which would enable a better understanding of which dimensions are more (or less) affected by the illusion of control and individual foresight practices.

In terms of research limitations, the illusion of control is a widely studied individual bias in the field of psychology. Ideally the investigation of its elements takes place through experiments, which portray with greater specificity the behavior pattern of the respondents. The establishment of a construct that represents the illusion of control was based on bibliography on the subject and validated in this study. However, adjustments may be necessary taking into account that the 
sample corresponds to Brazilian executives, from two specific sectors, of various age groups and with diverse experience times. The analysis of the results itself, creating distinct models for these different characteristics of the respondents, was made impossible due to the size of the sample, which also represents a limitation of the study and a possibility of future studies.

\section{REFERENCES}

Abdelrahman, M. (2008). Ananalysisoftheperceivedvalueofusingknowledge management systems in supporting decision making processes.

Aguilar, F. Scanning the business environment. Macmillan, 1967

Ajzen, I. (1991). The theory of planned behavior. Organizational behavior and human decision processes, 50(2), 179-211.

Alpert, M., \& Raiffa, H. (1982). A progressreportonthe training ofprobabilityassessors, in "JudgmentunderUncertainty: HeuristicsandBiases"(D. Kahneman, P. Slovic, and A. Tversky, Eds.).

Ansoff, H.I. (1975). Managing strategic surprise by response to weak signals. California management review, 18(2), 21-33.

Baratella, F.D.M. (2007). Excesso de confiança: estudantes versus gerentes.

Barnes Jr, J.H. (1984). Cognitive biases and their impact on strategic planning. Strategic Management Journal, 5(2), 129-137.

Barron, A., Hultén, P., \& Vanyushyn, V. (2015). Country-of-origin effects on managers' environmental scanning behaviours: evidence from the political crisis in the Eurozone. Environment and Planning C: Government and Policy, 33(3), 601-619.

Battistella, C. (2014). The organisation of Corporate Foresight: A multiple case study in the telecommunication industry. Technological Forecasting and Social Change, 87, 60-79.

Bazerman, M.H., \& Moore, D.A. (1994). Judgment in managerial decision making (p. 226). New York: Wiley.

Blenko, M.W., Mankins, M.C., \& Rogers, P. (2010). The decision-driven organization. Harvard Business Review, 88(6), 54-62.

Boksberger, P.E., \& Melsen, L. (2011). Perceived value: a critical examination of definitions, concepts and measures for the service industry. Journal of services marketing, 25(3), 229-240.

Borges, N.M. \& Janissek-Muniz, R. The environmental scanning as an informal and individual practice in organizations. In: Anais 9o IFBAE. Poitiers-France: 2017

Borges, N.M., \& Janissek-Muniz, R. (2018). Individual environmental scanning as a barrier to collective processes in organizations: A view based on the illusion of control. REGE Revista de Gestão, 25(3), 321-335.

Borges, N. M. (2020). Valor percebido a processos de Foresight nas organizaçôes: uma visão sob a lente da Teoria da Ilusão de Controle. Tese de Doutorado.

Brei, V.A., \& Rossi, C.A.V. (2005). Confiança, valor percebido e lealdade em trocas relacionais de serviço: um estudo com usuários de internet banking no Brasil. Revista de Administração Contemporânea, 9(2), 145-168.

Buehler, R., Griffin, D., \& Ross, M. (1994). Exploring the” planning fallacy”: Why people underestimate their task completion times. Journal of personality and social psychology, 67(3), 366. 
Buehring, J.H., \& Liedtka, J. (2018). Embracing systematic futures thinking at the intersection of Strategic Planning, Foresight and Design. Journal of innovation management.

Busenitz, L. W., \& Barney, J. B. (1997). Differencesbetweenentrepreneursand managers in largeorganizations: Biasesandheuristics in strategicdecision-making. Journalof business venturing, 12(1), 9-30.

Chekurov, S., Metsä-Kortelainen, S., Salmi, M., Roda, I., \& Jussila, A. (2018). The perceived value of additively manufactured digital spare parts in industry: An empirical investigation. International Journal of Production Economics, 205, 87-97.

Chin, W.W. (1998). The partial least squares approach to structural equation modeling. Modern methods for business research, 295(2), 295-336.

Choo, C.W., \& Nadarajah, I. (2014). Early warning information seeking in the 2009 Victorian Bushfires. Journal of the Association for Information Science and Technology, 65(1), 84-97.

Christensen-Szalanski, J.J., \& Bushyhead, J.B. (1981). Physicians' use of probabilistic information in a real clinical setting. Journal of Experimental Psychology: Human perception and performance, 7(4), 928.

Clayson, D.E. (2005). Performance overconfidence: metacognitive effects or misplaced student expectations?. Journal of Marketing Education, 27(2), 122-129.

Coates, J. F. (1985). Foresight in federal governmentpolicymaking. Futures ResearchQuarterly, 1(2), $29-53$.

Cohen, J. (1988). Statistical power analysis for the behavioral sciences. Lawrence Erlbaum Associates. Disponível em: http://utstat.toronto.edu/ - brunner/oldclass/378f16/readings/CohenPower.pdf

Dane, E., \& Pratt, M. G. (2007). Exploring intuition and its role in managerial decision making. Academy of management review, 32(1), 33-54.

Das, T.K., \& Teng, B.S. (1999). Managing risks in strategic alliances. Academy of Management Perspectives, 13(4), 50-62.

Davis, F.D. (1989). Perceived usefulness, perceived ease of use, and user acceptance of information technology. MIS quarterly, 319-340.

Davis, F.D., Bagozzi, R.P., \& Warshaw, P.R. (1992). Extrinsic and intrinsic motivation to use computers in the workplace 1. Journal of applied social psychology, 22(14), 1111-1132.

De Charms, R. (2013). Personal causation: The internal affective determinants of behavior. Routledge.

Dijksterhuis, A., Bos, M. W., Nordgren, L. F., \& Van Baaren, R. B. (2006). On making the right choice: The deliberation-without-attention effect. Science, 311(5763), 1005-1007.

Duhaime, I. M., \& Schwenk, C. R. (1985). Conjectures on cognitive simplification in acquisition and divestment decision making. Academy of Management Review, 10(2), 287-295.

Durand, R. (2003). Predicting a firm's forecasting ability: The roles of organizational illusion of control and organizational attention. Strategic Management Journal, 24(9), 821-838.

Durand, R. (2004). Can Illusion of Control Destroy a Firm's Competence? The Case of Forecasting Ability. Managing the Future, 109.

Du Toit, A. S. (2016). Usingenvironmentalscanningtocollectstrategicinformation: A South Africansurvey. InternationalJournalofInformation Management, 36(1), 16-24. 
Edward, R.J., \& Schoemaker Paul, J.H. (1992). Managing overconfidence. Sloan Management Review, 33(2).

Faul, F., Erdfelder, E., Lang, A.G., \& Buchner, A. (2007). G* Power 3: A flexible statistical power analysis program for the social, behavioral, and biomedical sciences. Behavior research methods, 39(2), 175-191.

Ferreira, C.F., \& Yu, A.S.O. (2003). Todos acima da média: excesso de confiança em profissionais de finanças. Revista de Administração da Universidade de São Paulo, 38(2).

Fishbein, M., \& Azjen, I. (1975). Formation of intentions. Belief, attitude, intention, and behavior: an introduction to theory and research.

Fornell, C., \& Larcker, D.F. (1981). Structural equation models with unobservable variables and measurement error: Algebra and statistics.

Garg, V.K., Walters, B.A., \& Priem, R.L. (2003). Chief executive scanning emphases, environmental dynamism, and manufacturing firm performance. Strategic management journal, 24(8), 725-744.

Gosling, M., \& Lago, J. (2006). Dimensões do valor percebido ea influência no boca-a-boca: reflexões teóricas e proposição de um modelo. REAd-Revista Eletrônica de Administração, 12(5), 345-368.

Graham, J.R., Harvey, C.R., \& Huang, H. (2009). Investor competence, trading frequency, and home bias. Management Science, 55(7), 1094-1106.

Hair, J. F., Black, W. C., Babin, B. J., Anderson, R. E., \& Tatham, R. L. (2009). Análise multivariada de dados. Bookman editora.

Hair, J.F., Ringle, C.M., \& Sarstedt, M. (2011). PLS-SEM: Indeed a silver bullet.Journal of Marketing theory and Practice, 19(2), 139-152.

Hair Jr, J., Sarstedt, M., Hopkins, L., \& G. Kuppelwieser, V. (2014). Partial least squares structural equation modeling (PLS-SEM) An emerging tool in business research. European Business Review, 26(2), 106-121.

Hair Jr, J. F., Hult, G. T. M., Ringle, C., \& Sarstedt, M. (2016). A primer onpartialleastsquaresstructuralequationmodeling (PLS-SEM). Sagepublications.

Hammond, T.B., \&Horswill, M.S. (2001). The influence of desire for control on drivers' risk-taking behaviour. Transportation research part F: traffic psychology and behaviour, 4(4), 271-277.

Harrysson, M., Métayer, E., \& Sarrazin, H. (2014). The strength of 'weak signals'. McKinsey Quarterly, $1,14-17$.

Jennings, D.F., \& Lumpkin, J.R. (1992). Insights between environmental scanning activities and Porter's generic strategies: An empirical analysis. Journal of Management, 18(4), 791-803.Kahneman, D., \&Lovallo, D. (1993). Timid choices and bold forecasts: A cognitive perspective on risk taking. Management science, 39(1), 17-31.

Kahneman, D., \& Lovallo, D. (1993). Timidchoicesandboldforecasts: A cognitive perspective onrisktaking. Management science, 39(1), 17-31.

Kahneman, D., \& Riepe, M.W. (1998). Aspects of investor psychology. Journal of portfolio management, 24(4), 52.

Kahneman, D., \& Tversky, A. (2013). Prospect theory: An analysis of decision under risk. In Handbook of the fundamentals of financial decision making: Part I (pp. 99-127). 
Kaivo-oja, J. (2017). Towards better participatory processes in technology foresight: How to link participatory foresight research to the methodological machinery of qualitative research and phenomenology?.Futures, 86, 94-106.

Keh, H.T., Der Foo, M., \& Lim, B.C. (2002). Opportunity evaluation under risky conditions: The cognitive processes of entrepreneurs. Entrepreneurship theory and practice, 27(2), 125-148.

Kidd, J.B. (1970). The utilization of subjective probabilities in production planning. Acta psychologica, 34, $338-347$.

Klayman, J., Soll, J.B., González-Vallejo, C., \& Barlas, S. (1999). Overconfidence: It depends on how, what, and whom you ask. Organizational behavior and human decision processes, 79(3), 216-247.

Koller H. (2009) Intercultural technology intelligence - a process and communication oriented approach. R. Meckl, R. Mu, F. Meng (Eds.), Technology and Innovation Management. Theories, Methods and Practices From Germany and China, Oldenbourg, München (2009), pp. 71-83

Koufteros, X. A. (1999). Testing a modelofpullproduction: a paradigm for manufacturingresearchusingstructuralequationmodeling. Journalofoperations Management, 17(4), 467-488.

Kuligowski, E.D., \& Gwynne, S.M. (2010). The need for behavioral theory in evacuation modeling. In Pedestrian and evacuation dynamics 2008 (pp. 721-732). Springer, Berlin, Heidelberg.

Kumar, K., Subramanian, R., \& Strandholm, K. (2001). Competitive strategy, environmental scanning and performance: a context specific analysis of their relationship. International Journal of commerce and Management, 11(1), 1-33.

Lacerda, T.S., \& Mendonça, B.Q. (2010). Marketing B2B: mapeamento dos trabalhos acadêmicos no Brasil de 1998 a 2007. Revista de Administração da Universidade Federal de Santa Maria, 3(2), 219-229.

Langer, E.J. (1975). The illusion of control. Journal of personality and social psychology, 32(2), 311.

Laroche, H., \& Nioche, J.P. (2015). L'approchecognitive de lastratégie d'entreprise. Revuefrançaise de gestion, 41(253), 97-120.

Lau, R. Y., Liao, S. S., Wong, K. F., \& Chiu, D. K. (2012). Web 2.0 environmental scanning and adaptive decision support for business mergers and acquisitions. MIS quarterly, 36(4), 1239-1268.

Lesca, H. VeilleStratégique: La méthode LE SCAnning: EMS, France, 2003.

Li, F., Su., Higgins, A. (2015). How Dynamic Capabilities affect adoption of management innovations. Journalof Business Research.

Malhotra, N. (2012). Pesquisa de marketing: uma orientaçâo aplicada (6a ed.). Porto Alegre: Bookman.

March, J.G., \& Shapira, Z. (1987). Managerial perspectives on risk and risk taking. Management science, 33(11), 1404-1418.

Meissner, P., \& Wulf, T. (2016). Debiasing illusion of control in individual judgment: the role of internal and external advice seeking. Review of Managerial Science, 10(2), 245-263.

Merkle, C. (2017). Financial overconfidence over time: Foresight, hindsight, and insight of investors. Journal of Banking \& Finance, 84, 68-87.

Milkman, K.L., Chugh, D., \& Bazerman, M.H. (2009). How can decision making be improved?. Perspectives on psychological science, 4(4), 379-383. 
BBR

18

Montier, J. (2009). Behavioural investing: a practitioner's guide to applying behavioural finance. John Wiley \& Sons.

Moore, D.A., Tanlu, L., \& Bazerman, M.H. (2010). Conflict of interest and the intrusion of bias. Judgment and Decision Making, 5(1), 37.

Niazi, M., \& Babar, M.A. (2009). Identifying high perceived value practices of CMMI level 2: An empirical study. Information and software technology, 51(8), 1231-1243.

Odean, T. (1998). Volume, volatility, price, and profit when all traders are above average. The journal offinance, 53(6), 1887-1934.

Omer, H., \& Alon, N. (1994). The continuity principle: A unified approach to disaster and trauma. American Journal of Community Psychology, 22(2), 273-287.

Oskamp, S. (1965). Overconfidence in case-study judgments. Journal of consulting psychology, 29(3), 261.

Peter, M.K., \& Jarratt, D.G. (2015). The practice of foresight in long-term planning. Technological Forecasting and Social Change, 101, 49-61.

Peterson, J.J. (2008). Appropriate factors to consider when assessing analytic confidence in intelligence analysis. Master of Science Thesis, Department of Intelligence Studies, Mercyhurst College, Erie, Pennsylvania.

Petrick, J. F. (2002). Developmentof a multi-dimensionalscale for measuringtheperceivedvalueof a service. Journalofleisureresearch, 34(2), 119-134.

Popper, R. (2008). How are foresight methods selected? Foresight-The journal offuture studies, strategic thinking and policy, 10(6), 62-89

Presson, P.K., \& Benassi, V.A. (1996). Illusion of control: A meta-analytic review.Journal of social behavior and personality, 11(3), 493.

Ringle, C.M., Da Silva, D., \& Bido, D.D.S. (2014). Modelagem de equaçóes estruturais com utilização do SmartPLS. Revista Brasileira de Marketing, 13(2), 56-73.

Reger, G. (2001). Technology foresight in companies: fromanindicatorto a network andprocess perspective. Technology Analysiser Strategic Management, 13(4), 533-553.

Rohrbeck, R. (2012). Exploring value creation from corporate-foresight activities. Futures, 44(5), 440-452.

Rohrbeck, R., \& Schwarz, J.O. (2013). The value contribution of strategic foresight: Insights from an empirical study of large European companies. Technological Forecasting and Social Change, 80(8), 1593-1606.

Rohrbeck, R., Battistella, C., \& Huizingh, E. (2015). Corporate foresight: An emerging field with a rich tradition. Technological Forecasting and Social Change, 101, 1-9.

Ruff, F. (2006). Corporate foresight: integrating the future business environment into innovation and strategy. International Journal of Technology Management, 34(3-4), 278-295.

Sarpong, D., \& Maclean, M. (2014). Unpacking strategic foresight: A practice approach. Scandinavian Journal of Management, 30(1), 16-26.

Schoemaker, P. J. (2019). Attention and foresight in organizations. Futures \& Foresight Science, 1(1), e5.

Schwenk, C.R. (1984). Cognitive simplification processes in strategic decision-making. Strategic management journal, 5(2), 111-128. 
Schwenk, C.R. (1988). The cognitive perspective on strategic decision making. Journal of management studies, 25(1), 41-55.

Simon, M., Houghton, S.M., \& Aquino, K. (2000). Cognitive biases, risk perception, and venture formation: How individuals decide to start companies. Journal of business venturing, 15(2), 113-134.

Sivanathan, N., Pillutla, M.M., \& Murnighan, J.K. (2008). Power gained, power lost. Organizational Behavior and Human Decision Processes, 105(2), 135-146.

Skinner, E.A. (1995). Perceived control, motivation, orcoping(Vol. 8). Sage.

Slaughter, R A. (1990). The foresight principle. Futures, 22(8), 801-819.

Soares, S.A., Florêncio, J.G., Assis, J.D.A.D., Digolin, K., Gontijo, R., \& Canesin, R.M. (2019). Alcances, limites e antinomias de métodos e técnicas em cenários prospectivos.

Stefan, S., \& David, D. (2013). Recent developments in the experimental investigation of the illusion of control. A meta-analytic review. Journal of Applied Social Psychology, 43(2), 377-386.

Svenson, O. (1981). Are we all less risky and more skillful than our fellow drivers?.Actapsychologica, 47(2), 143-148.

Tapinos, E., \& Pyper, N. (2018). Forward looking analysis: Investigating how individuals 'do' foresight and make sense of the future. Technological Forecasting and Social Change, 126, 292-302.

Taylor, S.E., \& Brown, J.D. (1988). Illusion and well-being: a social psychological perspective on mental health. Psychological bulletin, 103(2), 193.

Tversky, A., \& Kahneman, D. (1974). Judgment under uncertainty: Heuristics and biases. science, 185(4157), 1124-1131.

Venkatesh, V., Morris, M.G., Davis, G.B., \& Davis, F.D. (2003). User acceptance of information technology: Toward a unified view. MIS quarterly, 425-478.

White, R.W. (1959). Motivation reconsidered: The concept of competence. Psychological review, 66(5), 297. 


\section{Research Instrument.}

\begin{tabular}{|c|c|c|c|c|c|c|c|}
\hline 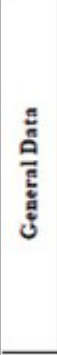 & 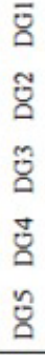 & 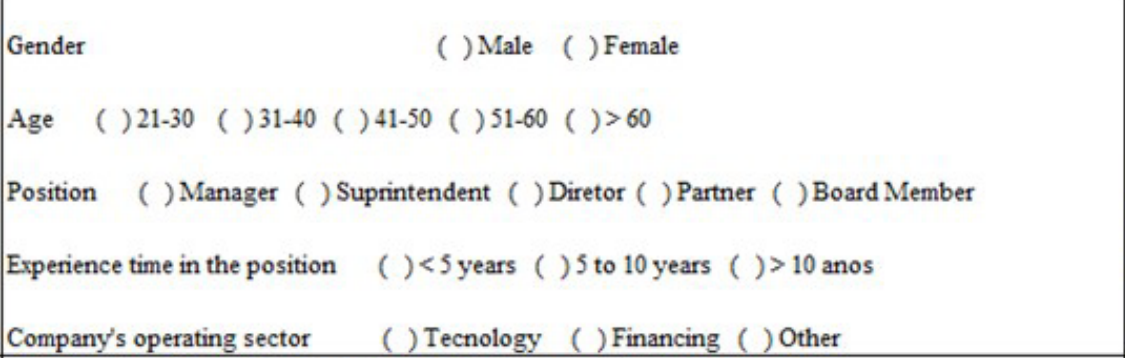 & 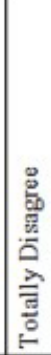 & 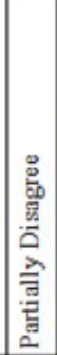 & 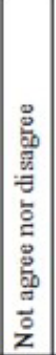 & 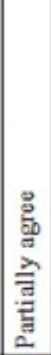 & 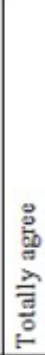 \\
\hline 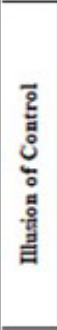 & $\begin{array}{l}\underline{\bar{U}} \\
\underline{\tilde{U}} \\
\underline{\underline{U}} \\
\underline{\underline{U}} \\
\underline{\varrho}\end{array}$ & $\begin{array}{l}\text { Compared to the people I work with and live with, my skills are above average. } \\
\text { In the work context, even in situations that involve uncertain information from the extemal } \\
\text { organizational environment, I keep control of the situation } \\
\text { It is unlikely that a disruptive situation will significantly affect the market where my company operates } \\
\text { My decisions are better than average (in the workplace) } \\
\text { I don't perceive the risk of sudden changes affecting my company's business in the short and medium } \\
\text { term. }\end{array}$ & & & & & \\
\hline 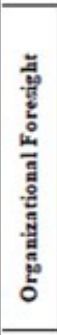 & 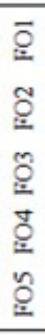 & $\begin{array}{l}\text { Your company has management mechanisms that keep it alert to changes in the market where it } \\
\text { operates } \\
\text { Your company performs routines for interpreting information and sensemaking to generate a better } \\
\text { understanding of the external environment } \\
\text { Your company usually has knowledge in advance about possible changes in its market } \\
\text { Your company has routines to identify, evaluate and collect external information and knowledge } \\
\text { Your company has databases where information relating to the market is organized and made available } \\
\text { to interested parties }\end{array}$ & & & & & \\
\hline 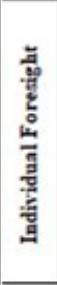 & 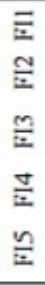 & $\begin{array}{l}\text { I tend to be aware of the changes that occur in the market where my organization operates. } \\
\text { I usually know in advance of possible changes in the market where my company operates. } \\
\text { I interpret and seek to make sense of the information that, in my view, can have an impact on the market } \\
\text { in which my company operates. } \\
\text { I try to organize information about the market so that I can access and share it. } \\
\text { I use information I collect individually from the company's extemal environment to make organizational } \\
\text { decisions }\end{array}$ & & & & & \\
\hline 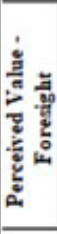 & 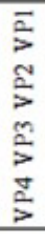 & $\begin{array}{l}\text { I would be more pleased to have a foresight process implemented in my company } \\
\text { My company would have better results if it had an ongoing foresight process } \\
\text { I would be more recognized in my work if I could count on the support of a foresight process } \\
\text { My decisions would be more reliable if there was a foresight process supporting me }\end{array}$ & & & & & \\
\hline 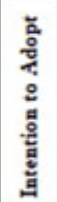 & $\begin{array}{l}\hat{\gtrless} \\
\hat{\varepsilon}\end{array}$ & $\begin{array}{l}\text { I am interested in implementing a foresight process in my company } \\
\text { The probability that I will implement foster aforesight process in my company is high } \\
\text { My interest in implementing a foresight process in my company is high }\end{array}$ & & & & & \\
\hline
\end{tabular}

